\title{
Eroosion torjunta, keskeinen toimenpide maatalouden vesiensuojelussa
}

\author{
Asko Särkelä ${ }^{1)}$, Paula Muukkonen ${ }^{2)}$, Pasi Valkama ${ }^{3)}$ ja Kirsti Lahti ${ }^{4)}$ \\ 1), 3), 4) Vantaanjoen ja Helsingin seudun vesiensuojeluyhdistys ry, Asemapäällikönkatu 12 C, 00520 \\ Helsinki,asko.sarkela@vesiensuojelu.fi, pasi.valkama@vesiensuojelu.fi.kirsti.lahti@vesiensuojelu.fi \\ ${ }^{2)}$ Helsingin yliopisto, Soveltavan kemian ja mikrobiologian laitos, paula.muukkonen@yahoo.com
}

Perinteinen syyskynnetty viljely jättää pellot osaksi vuotta ilman kasvipeitettä, jolloin ne ovat alttiina sateen ja sulamisvesien aiheuttamalle maa-aineksen huuhtoutumiselle. Pääosa vuoden kiintoaine- ja ravinnekuormituksesta kulkeutuu vesistöihin syksyn ja kevään aikana. Hienojakoisilta mailta tulevasta peltoviljelyn fosforikuormituksesta 75 - 90 \% tulee kiintoaineeseen sitoutuneena.

Maatalouden ympäristötukijärjestelmän tavoitteet vesistökuormituksen vähentämiseksi eivät ole suunnitellulla tavalla toteutuneet. Ympäristötuessa käytettyjä menetelmiä on käytetty jo irronneen ja virtaavan veden mukana kulkeutuvan kiintoaineen pysäyttämiseen. Näillä keinoilla pyritään hillitsemään jo tapahtuneen eroosion haittoja, jolloin puututaan vain yhteen eroosion osa-alueeseen eli kulkeutumiseen.

Suorakylvö on kuormitusta ennalta ehkäisevä toimenpide, joka kohdistuu koko lohkon alalle sekä pinta- että salaojavaluntaan. Se on tehokas tapa vähentää hienojakoisten maiden eroosiota ja sen mukana vesistöön kulkeutuvan fosforin kuormitusta. Toisaalta pintavalunnan mukana huuhtoutuvan liukoisen fosforin kuormitus voi olla suurempaa suorakylvö- kuin kyntöpelloilta, koska pellolle lisätyt lannoitteet kertyvät pellon pintakerrokseen.

Kynnön ja suorakylvön vaikutusta fosforin uuttumiseen tutkittiin analysoimalla häiriintymättömistä maaprofiileista kerättyjä vesinäytteitä. Läpivaluneen veden sameus, kiintoaine- ja partikkelimaisen fosforin pitoisuudet sekä huuhtoutuneet määrät olivat kynnössä suurempia kuin suorakylvössä. Maaprofiilin läpi suotautuvan veden liukoisen fosforin pitoisuuksissa ei sen sijaan havaittu eroja kynnön ja suorakylvön välillä. Tämä johtui todennäköisesti liukoisen fosforin pidättymisestä maahiukkasten pinnoille veden suodattuessa maakerrosten läpi.

Valumavesien pellolta kuljettamasta maa-aineksesta voi vapautua merkittäviä määriä fosforia leville käyttökelpoiseen muotoon. Suorakylvön vesiensuojelulliset hyödyt joudutaan arvioimaan sen mukaan, kuinka paljon sen avulla saadaan pienennettyä eroosiosta aiheutuvaa fosforikuormitusta ja toisaalta kuinka paljon suorakylvö lisää liukoisen fosforin kuormitusriskiä.

Mitä suurempi on maahiukkasen fosforipitoisuus ja mitä laimeampaa maahiukkasta ympäröivä liuos on, sitä enemmän maahiukkasesta voi liueta fosforia ympäröivään liuokseen. Kevättalvisin, lumen sulamisaikaan, on havaittu korkeita liukoisen fosforin pitoisuuksia peltovaltaisten valumaalueiden savisameissa ojavesissä. Missä määrin fosforin liukenemista maa-aineksesta tapahtuu rehevien ja humuspitoisten järvien hapettomissa syvänteissä sekä ojien suvannoissa kesällä tai jääpeitteen alla?

Eroosion vähentämiseen tulisi kiinnittää aiempaa suurempaa huomiota, sillä emme tiedä kuinka suuri osa eroosioaineksen sisältämästä fosforista lopulta muuttuu leville käyttökelpoiseksi matkalla pellolta ojien kautta jokiin ja järviin? Lisäksi ojien perkausten voidaan olettaa vähenevän samassa suhteessa kuin kiintoainekuormitusta pystytään hillitsemään.

Asiasanat: eroosio, suorakylvö, kyntö, fosforikuormitus 


\section{Johdanto}

Suorakylvössä maata ei muokata, vaan kasvusto perustetaan esikasvin sänkeen. Menetelmä on lähtöisin Yhdysvalloista, jossa suorakylvöön siirtymisen merkittävin syy on ollut eroosion vähentäminen. Suomessa suorakylvöala on kasvanut vauhdilla: vuonna 2002 se oli 30000 ha, vuonna 2008 yli 160000 ha. Sen ennustetaan kasvavan edelleen nykyisen maatalouden ympäristötuen kannustaessa talviaikaisen kasvipeitealan lisäämiseen. Viljelijät tavoittelevat suorakylvöön siirtymisellä ympäristökuormituksen vähentämisen ohella kustannus- ja työaikasäästöjä.

Perinteinen viljely, jossa pellot kynnetään syksyllä jättää pellot osaksi vuotta ilman kasvipeitettä, jolloin ne ovat alttiina sateen ja sulamisvesien aiheuttamalle maa-aineksen huuhtoutumiselle. Pääosa, usein jopa 90 \%, vuoden kiintoaine- ja ravinnekuormituksesta kulkeutuu vesistöihin syksyn ja kevään aikana (mm. Puustinen ym., 2007). Talvivaluntojen merkitys tulee nykyisten ilmastonmuutosennusteiden (IPCC, 2007) mukaan kasvamaan. Esimerkiksi lauha, sateinen talvi 2008 johti hankalan kuormitusjakson jatkumiseen lähes yhtenäisenä syksystä aina kevättulvaan saakka (Valkama, 2008). Toistuvat maan jäätymis- ja sulamisjaksot kasvattavat eroosiota ja ravinteiden huuhtoutumista. Eroosion myötä suuria määriä peltomaata valuu vesistöihin. Hienojakoisilta mailta tulevasta peltoviljelyn fosforikuormituksesta 75 - $90 \%$ tulee kiintoaineeseen sitoutuneena, kun taas karkeilla mailla suurempi osa fosforikuormituksesta tulee liukoisessa muodossa.

Maatalouden ympäristötukijärjestelmän tavoitteet vesistökuormituksen vähentämiseksi eivät ole kuluneen 14 vuoden aikana suunnitellulla tavalla toteutuneet. Ympäristötuessa käytettyjä menetelmiä, suojavyöhykkeitä ja kosteikkoja, on käytetty jo irronneen ja virtaavan veden mukana kulkeutuvan kiintoaineen pysäyttämiseen. Näillä keinoilla pyritään hillitsemään jo tapahtuneen eroosion haittoja, jolloin puututaan vain yhteen eroosion osa-alueeseen eli kulkeutumiseen (Valkama, 2005). Pintavalunnan on todettu keskittyvän maanpinnan taitekohtiin ja eroosiota tapahtuvan jo pienillä rinteen kaltevuuksilla.

Ympäristötukijärjestelmässä on keskitytty pääuomiin ja unohdettu sivu-uomat, jolloin suuri osa vesistöä kuormittavasta pelto-alasta on jäänyt vähälle huomiolle. Järjestelmässä ei siis ole keskitytty olennaiseen aikaan eikä paikkaan saati olennaiseen tekijään eli eroosioon.

Koska kasvillisuuden merkitys roiske- ja pintaeroosion estämisessä on todettu tärkeäksi, sen avulla voidaan tehokkaasti estää eroosion ensimmäinen vaihe eli maaperän hiukkasten irtoaminen. Suorakylvö on kuormitusta ennalta ehkäisevä toimenpide, joka kohdistuu koko lohkon alalle sekä pinta- että salaojavaluntaan toisin kuin menetelmät, joissa jo syntynyttä kuormitusta yritetään estää pääsemästä vesistöön. Sekä kansainvälisesti että Suomessa on todettu, että suorakylvö on tehokas tapa vähentää hienojakoisten maiden eroosiota ja sen mukana vesistöön kulkeutuvan fosforin kuormitusta (Chichester and Richardson, 1992; Lundekvam, 1998; Chambers et al., 2000; Puustinen et al., 2005, 2007). Todennäköisesti myös typen huuhtoutuminen vähenee hienojakoisten maiden suorakylvössä. Toisaalta pintavalunnan mukana huuhtoutuvan liukoisen fosforin kuormitus voi olla suurempaa suorakylvö- kuin kyntöpelloilta, koska pellolle lisätyt lannoitteet kertyvät pellon pintakerrokseen kasvattaen maahiukkasten fosforikyllästysastetta (mm. Alakukku ym., 2009).

Siirtyminen suorakylvöön on maan kannalta suurin muutos peltoviljelyssä sitten auraan tarttumisen, sillä se muuttaa aineiden sekoittumista maahan, eliöstön elinoloja ja maan rakennetta ja vaikuttaa siten sekä veden, ilman että ravinteiden kiertoon. Maan prosesseissa ja vastaanottavassa vesistössä tapahtuvien ilmiöiden tunteminen on oleellista selvitettäessä keinoja peltoviljelyn vesistökuormituksen vähentämiseksi.

Hankkeessa hyödynnettiin kahta vuonna 2000 Jokioisiin perustettua MTT:n savimaan koekenttää, joissa viljeltiin koejakson ajan ohraa ja kauraa. Kentiltä otettiin kynnetyistä ja suorakylvetyistä ruuduista näytteitä laboratoriotutkimuksiin, joissa selvitettiin aineiden liikkumista häiriintymättömässä maassa. Hankkeessa suunniteltiin ja rakennettiin tarkoitukseen soveltuva mittausmenetelmä, jolla tutkittiin aineiden liikkumista kyllästetyssä maassa. Kyllästetyssä tilassa tehty mittaus kertoo maasta uuttuvien aineiden potentiaalisen määrän kuvaten tilannetta esimerkiksi roudan sulamisen aikaan ja syyssateiden kastelemassa maassa. 


\section{Tulokset}

\section{Orgaaninen hiili ja fosfori kertyvät maan pintaan}

Deionisoidulla vedellä uutetun sekä viljavuustutkimuksessa ammoniumasetaatilla uutetun fosforin (ns. viljavuusfosforin) kertyminen maan pintakerrokseen oli selkeästi havaittavissa molemmilla Jokioisten koekentillä (Muukkonen ym., 2009) (kuva 1.), kuten myös Pyhäjärven ja Vantaanjoen alueiden suorakylvetyissä pelloissa (Alakukku ym., 2009). Suorakylvö oli selvästi nostanut orgaanisen hiilen ja helppoliukoisen fosforin pitoisuuksia maan pintakerroksessa. Vesiuutto kertoi selvemmin fosforin kertymisestä suorakylvömaiden pintakerrokseen kuin ammoniumasetaattiuutto (kuva 1). Pintakerroksen $\mathrm{pH}$ oli alhaisempi kuin kynnetyillä ruuduilla, mikä johtui todennäköisesti pellon pintaan kertyneiden typpilannoitteiden happamoittavasta vaikutuksesta. Kynnetyn maan $\mathrm{pH}$ ja orgaanisen aineen pitoisuus olivat keskimäärin samansuuruisia koko muokkauskerroksen alueella (0$20 \mathrm{~cm}$ ) (kuva 1).
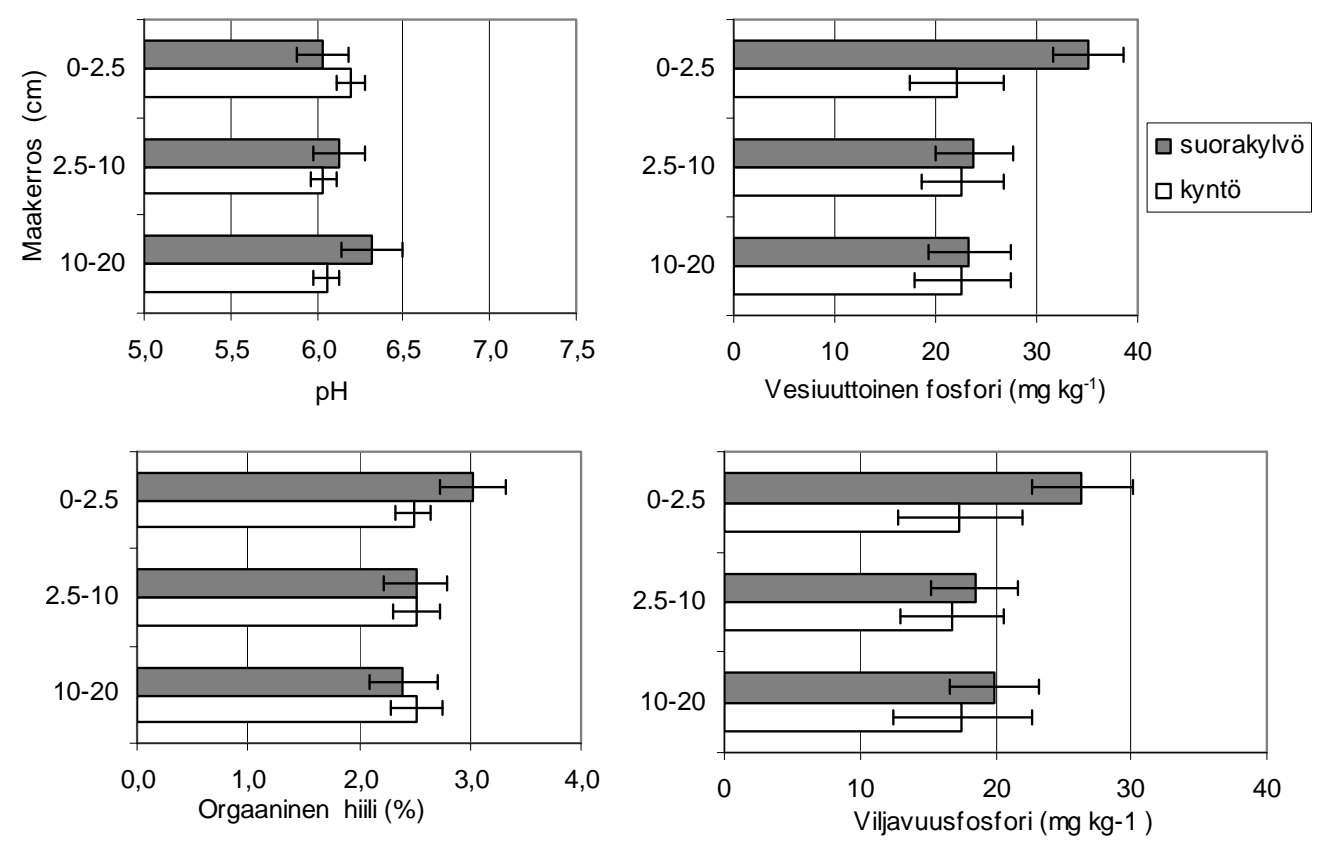

Kuva 1. Maan pH:n ja orgaanisen hiilen, vesiuuttoisen fosforin sekä ammoniumasetaattiuuttoisen fosforin, ns. viljavuusfosforin, pitoisuudet eri maakerroksissa suorakylvetyissä ja kynnetyissä maaprofiileissa. Janat kuvaavat 95 \%:n luottamusväliä

\section{Aineiden uuttuminen häiriintymättömästä maasta}

Kynnön ja suorakylvön vaikutusta fosforin uuttumiseen tutkittiin analysoimalla $0-20 \mathrm{~cm}$ maakerroksista otetuista häiriintymättömistä maaprofiileista kerättyjä vesinäytteitä. Maaprofiilinäytteet kyllästettiin laboratoriossa vedellä, niiden annettiin seistä kahden tunnin ajan ja näytteestä puolen tunnin aikana valunut vesi otettiin analysoitavaksi. Käsittely toistettiin kolme kertaa. Häiriintymättömistä 0-20 cm:n maaprofiileista valuneen veden määrä oli kenttien keskiarvona suorakylvettäessä $240 \pm 19 \mathrm{ml}$ ja kynnettäessä $314 \pm 36 \mathrm{ml}$. Kynnetyn maan makrohuokoston tilavuus, josta vesi uutettiin, oli siis suurempi kuin suorakylvetyn maan.

Läpivaluneen veden sameus, kiintoainepitoisuus ja partikkelimaisen fosforin pitoisuudet ja huuhtoutuneet määrät olivat kynnössä suurempia kuin suorakylvössä (kuvat 2 ja 3). Maaprofiilin läpi suotautuvan veden liukoisen fosforin pitoisuuksissa ei sen sijaan havaittu eroja kynnettyjen ja suorakylvettyjen maanäytteiden välillä (kuva 3). Tämä johtui todennäköisesti liukoisen fosforin pidättymisestä maahiukkasten pinnoille veden suodattuessa alaspäin maakerrosten läpi. Fosforipitoisuudet peräkkäisissä valumavesissä olivat lähes samansuuruisia. Savimaa luovuttaakin fosforia tasaisesti ympäröivään veteen (Muukkonen, 2009), toisin kuin karkeammat maalajit, joista fosfori huuhtoutuu helpommin "piikkeinä”. Tämä johtuu siitä, että savimaissa on enemmän fosforia pidättäviä raudan ja alumiinin oksideja kuin karkeissa maissa (Hartikainen, 1982). 


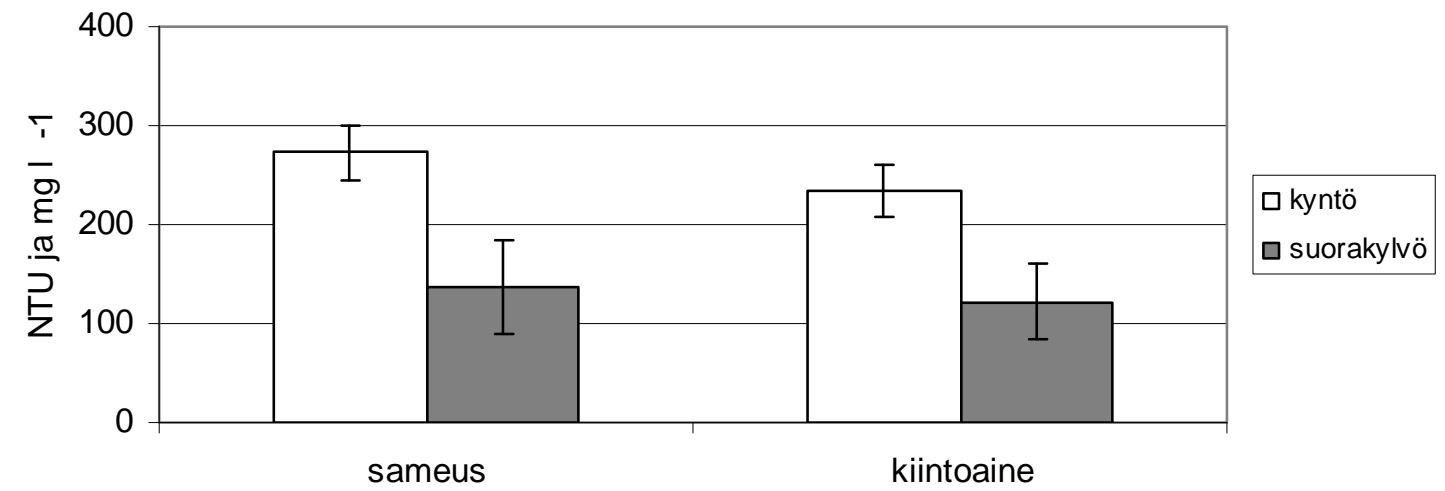

Kuva 2. Häiriintymättömien maaprofiilien $(0-20 \mathrm{~cm})$ läpi suotautuneiden vesien sameus ja kiintoainepitoisuus suorakylvössä ja kynnössä. Janat kuvaavat 95 \%:n luottamusväliä.

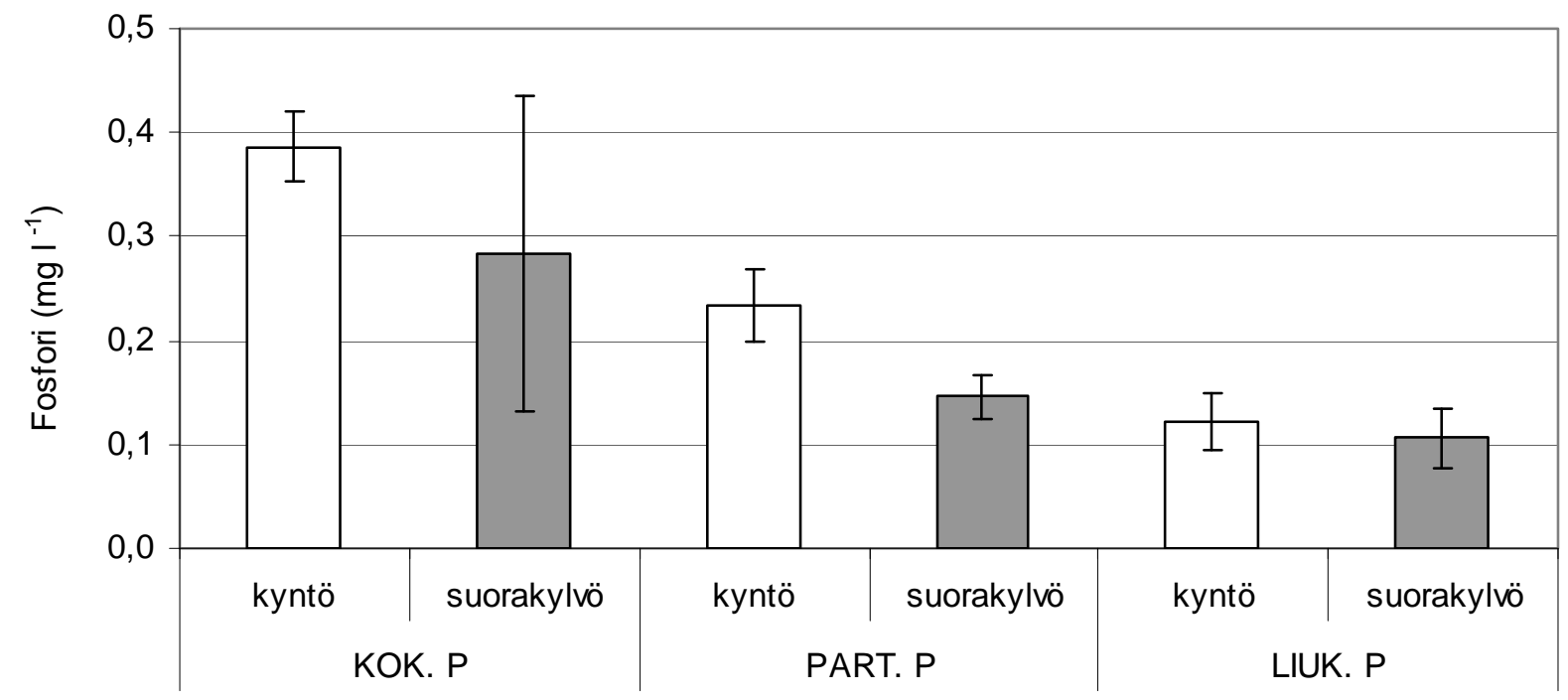

Kuva 3. Häiriintymättömien maaprofiilien $(0-20 \mathrm{~cm})$ läpi suotautuneiden vesien kokonais-, partikkelimaisensekä liukoisen fosforin pitoisuudet suorakylvössä ja kynnössä. Janat kuvaavat 95 \%:n luottamusväliä.

Maan murustamisen on todettu lisäävän huomattavasti valumavesien kiintoaine- ja kokonaisfosforipitoisuuksia. Maan muokkaus paljastaa tuoreita pintoja, jolloin maa-aineksen huuhtoutuminen lisääntyy ainakin hetkellisesti. Muukkosen ym. (2009) tutkimuksessa savimaiden rakenne rikottiin kyntöä jäljitellen $20 \mathrm{~cm}$ syvyyteen, jolloin valumavesien sameus kasvoi 10 - 13 kertaiseksi ja maa-ainekseen sitoutuneen fosforin pitoisuus 6,5 -kertaiseksi. Tällainen ilmiö on mahdollinen aina kynnön yhteydessä. Edellä esitetyissä määrityksissä uuttoneste oli deionisoitu vesi. Mitä suurempaan vesitilavuuteen maahiukkaset joutuivat, sitä enemmän niistä irtosi fosforia ympäröivään veteen (Muukkonen ym. 2007, 2009).

Hankkeessa käytettiin testauksen vuoksi uuttonesteenä myös viljavuusanalyysissä käytettävää hapanta ammoniumasetaattia. Tämän avulla haluttiin tutkia kuinka uuttoliuos, jonka suolapitoisuus on selkeästi korkeampi kuin deionisoidun veden, vaikuttaa maa-aineksen irtoamiseen häiriintymättömästä maaprofiilinäytteestä. Selkeä ero näkyi näytteestä ulostulevan uuttonesteen sameudessa. Ammoniumasetaattinesteet olivat deionisoituihin valumavesiin verrattuna selvästi kirkkaampia ja jos niissä oli maa-ainesta, se painui nopeasti muruina mittalasien pohjalle. Päättelimme tämän johtuvan uuttonesteen korkeammasta suolapitoisuudesta: suolapitoinen neste ei hajota maan rakennetta samalla tavoin kuin laimea deionisoitu vesi tekee. Tutkimustuloksen perusteella voidaan todeta että maanesteen suolapitoisuuden nostolla voidaan periaatteessa vähentää savihiukkasten eroosioherkkyyttä. 


\section{Tulosten tarkastelu ja johtopäätökset \\ Kuormituksen hallinta suorakylvössä}

Suorakylvön vesiensuojelullisena ongelmana on fosforin kertyminen pellon pintakerrokseen. Tämä näyttää lisäävän liukoisen fosforin kuormitusriskiä suorakylvössä etenkin, jos pelloilta tulee paljon pintavaluntaa. Myös halkeilevilla savimailla tapahtuvat oikovirtaukset, joissa valumavesi ei ehdi reagoimaan ympäröivän maa-aineksen kanssa, ovat ongelmallisia liukoisen fosforin huuhtoutumisen kannalta. Sekä hienorakeisilla että karkeilla maalajeilla helppoliukoisen fosforin pitoisuus pintamaassa säätelee pintavalumavesiin liuenneen fosforin pitoisuuksia (Turtola ja Yli-Halla 1999). Savimailla fosforin kertyminen suorakylvöpeltojen pintaan ei kasvata fosforikuormitusriskiä yhtä nopeasti kuin karkeilla mailla, joilla pidätyspintaa on savimaita vähemmän.

Maan rakenteen parantamisella ja pintavalunnan estämisellä voidaan tehokkaasti vähentää liukoisen fosforin kuormitusta etenkin hienojakoisilla mailla. Hyvä vedenläpäisevyys on myös kasvien kasvun ja maan viljeltävyyden kannalta tärkeää. Suorakylvöstä poiketen muut kynnön sijaan tehtävät muokkaukset, joissa muokkaussyvyyttä ainoastaan rajoitetaan, saattavat jopa lisätä eroosiota kasvukauden ulkopuolella kyntöön verrattuna. Muokkaussyvyyden pienentäminen on esimerkiksi Jokioisten savimaalla tehdyissä tutkimuksissa lisännyt selvästi pintavalunnan määrää (Turtola, 2007). Maan vedenläpäisevyyden tärkeys korostuukin muokkausta kevennettäessä. Veden imeytyminen pinnasta syvempiin kerroksiin sateen jälkeen tulisi olla nopeaa, jotta pintavaluntaa ei syntyisi. Kyntömaissa veden imeytymistä edesauttaa kynnöksen suuri huokostilavuus.

Fosforilannoitukseen on kiinnitettävä entistä enemmän huomiota siirryttäessä kynnöstä suorakylvöön, sillä kaikki kasveilta käyttämättä jäänyt fosfori kertyy pellon pintakerrokseen. Liuenneen fosforin huuhtouman hallinnassa fosforilannoituksen tarkentaminen viljelykasvien todellisia tarpeita vastaavaksi on keino, joka hyödyttää viljelijää myös taloudellisesti.

Fosforilannoitussuositukset annetaan 0-20 cm maakerroksesta otettavien maanäytteiden perusteella. Kun suorakylvössä fosfori kertyy pellon ylimpään pintakerrokseen, niin $0-20 \mathrm{~cm}$ maaprofiilista tehtävä viljavuusuutto antaa todennäköisesti väärän kuvan suorakylvöpeltojen lannoitustarpeesta. Tulevaisuudessa suorakylvöpeltojen lannoitusohjeita tulisikin tarkentaa, mutta asiasta ei ole vielä tähän mennessä tehty tutkimusta.

Pelloilla joiden $\mathrm{pH}$ on alhainen mutta fosforitila on luokassa hyvä, korkea tai arveluttavan korkea, kasvien fosforin saantia voidaan turvata jokavuotisen fosforilannoituksen sijasta $\mathrm{mm}$. kalkitsemalla peltoja. Kalkitus parantaa fosforin käyttökelpoisuutta kasveille ja vaikuttaa positiivisesti myös maan rakenteeseen ja pieneliötoimintaan. Kalkituksen seurauksena maanesteen ionivahvuus nousee, mikä vähentää fosforin liukenemista maasta valumavesien mukaan pitäen kuitenkin fosforin kasveille käyttökelpoisessa muodossa.

\section{Fosforin rehevöittävät vaikutukset}

Valumavesien pellolta kuljettamasta maa-aineksesta voi vapautua merkittäviä määriä fosforia leville käyttökelpoiseen muotoon. Suorakylvön vesiensuojelulliset hyödyt joudutaan arvioimaan sen mukaan, kuinka paljon sen avulla saadaan pienennettyä eroosiosta aiheutuvaa fosforikuormitusta ja toisaalta kuinka paljon suorakylvö lisää liukoisen fosforin kuormitusriskiä.

Huuhtoutumiskentiltä kerätyillä valumavesillä tehtyjen tutkimusten mukaan eroosioaineksesta saattaa hapellisissa oloissa, eroosioaineksen matkatessa pellolta vesistöön, vapautua suuruusluokaltaan saman verran leville käyttökelpoista fosforia kuin valumavesissä on liuennutta fosforia. Voimakkaasti pelkistyneissä oloissa voi lisäksi vapautua noin puolet kiintoaineksen sisältämästä fosforista (Uusitalo, 2004). Vuosien 1997 - 2001 aikana tehdyn seurannan mukaan Aurajoen, Kotkanojan ja Lintupajun koekentiltä kynnetyiltä ruuduilta tulevassa pintavalunnassa fosforin kokonaismäärästä oli liuenneessa muodossa $14 \%$, hapellisissa oloissa leville käyttökelpoiseen muotoon vapautuvaa eroosioaineksen fosforia samoin $14 \%$ ja voimakkaasti pelkistyneissä oloissa (pitkä hapettomuusjakso) eroosioaineksesta vapautuvaa fosforia keskimäärin $37 \%$ (Uusitalo, 2004). Luvut korostavat eroosioaineksen merkitystä rehevöittävän fosforikuorman synnyssä. Mainituilta hienojakoisilta huuhtoutumiskoekentiltä tulevasta fosforista oli 80-90 \% kiintoaineksen mukana kulkeutuvaa. Liuenneen fosforin osuus on yllä mainittua suurempi karkeammilta mailta tulevassa valunnassa, joten suorakylvön vesiensuojelulliset edut eivät niillä tule esiin niin selkeästi kuin hienojakoisilla mailla. 
Suorakylvön vesiensuojelulliset hyödyt kyntöön nähden ovat myös pienempiä hienojakoisilla mailla, joiden maan pintakerroksen fosforipitoisuus on korkea ja eroosiomäärät vähäisiä.

Vedessä maahiukkasiin sitoutuneeseen fosforiin vaikuttavat lukuisat fysikaaliset, kemialliset ja biologiset prosessit ja siten kiintoaineeseen sitoutunut fosfori aiheuttaa joka tapauksessa suuren kuormituspotentiaalin. Vesistöissä partikkeleista vapautuu sitä enemmän fosforia, mitä väljempään ja vähäsuolaisempaan veteen ne päätyvät. Mitä suurempi on maahiukkasen fosforipitoisuus ja mitä laimeampaa maahiukkasta ympäröivä liuos on, sitä enemmän maahiukkasesta voi liueta fosforia ympäröivään liuokseen (Yli-Halla ym. 2002, Muukkonen 2007). Vesiensuojeluyhdistyksen mittauksissa on kevättalvisin, lumen sulamisaikaan, havaittu korkeita liukoisen fosforin pitoisuuksia (65 - 80 \% kokonaisfosforipitoisuudesta) peltovaltaisten valuma-alueiden savisameissa ojavesissä. Mikä osuus tästä on sulaneesta kasvimassasta vapautuvaa ja toisaalta maahiukkasista laimeassa liuoksessa vapautuvaa liukoista fosforia, on epäselvää.

Missä määrin fosforin liukenemista tapahtuu rehevien ja humuspitoisten järvien hapettomissa syvänteissä sekä hitaasti virtaavien ojien suvannoissa kesällä tai jääpeitteen alla? Vantaanjoen ja Helsingin seudun vesiensuojeluyhdistyksen automaattisessa veden laadun seurannassa on ajoittain tulva-aikoina havaittu happikatoja mitta-antureiden hautauduttua sedimenttiin. Jokiekosysteemi on sedimentoitumisen ja kulkeutumisen monimutkainen kokonaisuus. Voidaan siis perustellusti kysyä missä määrin sillä on merkitystä, missä muodossa fosfori kulkeutuu pellolta vesistöihin?

On hämmästyttää, miten suuren painoarvon liukoisen fosforin mahdollinen vapautuminen suorakylvetyn pellon pintamaasta on saanut tutkijoiden parissa. Eroosion vähentämiseen tulisi kiinnittää aiempaa suurempaa huomiota, sillä emme tiedä kuinka suuri osa eroosioaineksen sisältämästä fosforista lopulta muuttuu leville käyttökelpoiseksi matkalla pellolta ojien kautta jokiin ja järviin? Lisäksi ojien perkausten voidaan olettaa vähenevän samassa suhteessa kuin kiintoainekuormitusta pystytään hillitsemään.

Suorakylvöllä ja talviaikaisella kasvipeitteisyydellä vaikutetaan koko peltoalaan, sekä pinta- että salaojavaluntaan, toisin kuin monilla muilla maatalouden ympäristötuessa käytetyillä menetelmillä, joissa vaikutus kohdistuu vain murto-osaan peltoalasta. Ei siis ihmekään, että maatalouden ympäristötuessa käytetyt menetelmät eivät ole vaikuttaneet toivotulla tavalla kuormitusta vähentävästi. Toisaalta, pystytäänkö sitä perinteisin näytteenottomenetelmin edes havaitsemaan? Näytteenottoajankohdalla ja -tiheydellä on suuri merkitys laskentajakson kuormituslaskentojen tuloksiin. Vesiensuojeluyhdistyksen automaattisilla veden laadun mitta-antureilla tekemien tutkimusten perusteella perinteisin menetelmin tehdyt, ylivirtaamakausia painottavat kuormituslaskelmat yliarvioivat kokonaiskuormien määriä moninkertaisesti, etenkin pienissä virtavesissä. Esimerkiksi kiintoaine- ja kokonaisfosforipitoisuudessa tapahtuvat muutokset ovat niin nopeita, että näytteenottohetken siirtäminen muutamalla tunnilla eteenpäin voi muuttaa tulosta kymmenkertaisesti (Valkama, 2007).

\section{Kirjallisuus:}

Alakukku, L., Uusitalo, R., Särkelä, A., Lahti, K., Valkama, P., Valpasvuo-Jaatinen, P. \& Ventelä, A.-M. 2009. Phosphorus stratification in the Ap horizon of ploughed and no-till soils and its effect on P forms in surface runoff. ISTRO 18. Triennial Conference Proceedings, June 15-19, 2009 Izmir-Turkey.

Chambers, B.J., Garwood, T.W.D. \& Unwin, R.J. 2000. Controlling soil water erosion and phosphorus losses from arable land in England and Wales. Journal of Environmental Quality 29, 145-150.

Chichester, F.W. \& Richardson, C.V. 1992. Sediment and nutrient loss from clay soils as affected by tillage. Journal of Environmental Quality 21, 587-590.

Hartikainen, H. 1982.Water soluble phosphorus in Finnish mineral soils and its dependence on soil properties. Journal of the Scientific Agricultural Society of Finland 54, 89-98.

IPCC. 2007. Climate Change 2007: Synthesis Report. 52 p. Available: http://www.ipcc.ch/pdf/assesmentreport/ar4/syr/ar4_syr.pdf

Lundekvam, H. 1998. P-losses from three soil types at different cultivation systems. In: Phosphorus balance and utilization in agriculture - towards sustainability. (Editor Agerlid, G.). pp. 177-185. Seminarium, den 17-19 mars 1997. Kungliga Skogs- och Lantbruksakademiens Tidskrift 137.

Muukkonen, P., Hartikainen, H., Lahti, K., Särkelä, A., Puustinen, M. \& Alakukku, L. 2007. Influence of no-tillage on the distribution and lability of phosphorus in clay soils. Agriculture, Ecosystems \& Environment 120: 299-306. 
Muukkonen, P., Hartikainen, H., \& Alakukku, L. 2009. Effect of soil structure disturbance on erosion and phosphorus losses from Finnish clay soil. Soil \& Tillage Research 103: 84-91.

Puustinen, M., Koskiaho, J. \& Peltonen, K. 2005. Influence of cultivation methods on suspended solids and phosphorus concentrations in surface runoff on clayey sloped fields in boreal climate. Agriculture, Ecosystems \& Environment 105, 565-579.

Puustinen, M., Tattari, S., Koskiaho, J. \& Linjama, J. 2007. Influence of seasonal and annual hydrological variations on erosion and phosphorus transport from arable areas in Finland. Soil \& Tillage Research 93, 44-55.

Turtola, E. and M. Yli-Halla. 1999. Fate of phosphorus applied in slurry and mineral fertilizer: Accumulation in soil and release into surface runoff water. Nutr. Cycl. Agroecosyst. 55: 165-174.

Turtola, E. 2007: Surface runoff, subsurface, drainflow and soil erosion as affected by tillage in a clayey Finnish Soil. Agricultural and Food Science 16:332-351.

Uusitalo, R. 2004. Potential availability of particulate phosphorus in runoff from arable clayey soils. Academic dissertation. Agrifood Research Reports 53. Jokioinen. 99 p. +4 append.

Valkama, P. 2004. Virtaavan veden aiheuttama eroosio ja sen ehkäisy. Vantaanjoen ja Helsingin seudun vesiensuojeluyhdistyksen julkaisu 53/2004: 49 s.

Valkama, P., Lahti K. \& Särkelä, A. 2007. Fosforikuormituksen arviointi pelto-ojan valuma-alueelta ylivirtaama-aikoina. Vesitalous 5:30-34.

Valkama, P., Lahti, K. \& Särkelä, A. 2008. Fosfori- ja typpikuormituksen muodostuminen Lepsämänjoessa kevät- ja syystulvatilanteissa. Vesitalous 5: 26-30.

Yli-Halla, M., Hartikainen, H. \& Väätäinen, P. 2002. Depletion of soil phosphorus as assessed by several indices of phosphorus supplying power. European Journal of Soil Science 53, 431-438. 